\title{
PEMBAHARUAN KEBIJAKAN PIDANA KEJAHATAN PERDAGANGAN ORANG (STUDI DI WILAYAH PERBATASAN KALIMANTAN BARAT-SARAWAK)
}

\author{
Syarif Hasyim Azizurrahman \\ Fakultas Hukum Universitas Tanjungpura Pontianak \\ Email : hasyimsyarif@yahoo.co.id
}

\begin{abstract}
Law. 21 of 2007 already contained the formulation of the Crime of Trafficking in Persons, but criminal law policies contained insufficient to combat human trafficking in West Kalimantan-Sarawak border, because it has not been formulated based on the modus operandi and the prediction of the development of the crime of trafficking in persons in the border region, so it needs to be done renewal.
\end{abstract}

Keywords: Trafficking Crime, criminal law policy, criminal law Updates

\begin{abstract}
Abstrak
UU No. 21 Tahun 2007 telah memuat rumusan Tindak Pidana Perdagangan orang, namun kebijakan hukum pidana yang dimuat belum memadai untuk memberantas perdagangan orang di wilayah perbatasan Kalimantan Barat-Sarawak, karena belum diformulasikan berdasarkan modus operandi dan prediksi perkembangan kejahatan perdagangan orang di wilayah perbatasan, sehingga perlu dilakukan pembaharuan.
\end{abstract}

Kata Kunci: Kejahatan Perdagangan orang, Kebijakan hukum pidana, Pembaharuan hukum pidana

\section{A. Pendahuluan}

Pemerintah Republik Indonesia merumuskan Undang-Undang Nomor 21 Tahun 2007 Tentang Pemberantasan Tindak Pidana Perdagangan orang (UU No. 21 Tahun 2007) merupakan salah satu pencermatan dari Konvensi Palermo tahun 2000 dan protokol Perserikatan Bangsa-Bangsa (PBB) untuk pencegahan, pemberantasan dan pemidanaan pelaku perdagangan manusia khususnya perempuan dan anak.

UU No. 21 Tahun 2007, Pasal 1 angka 1 mendefinisikan Perdagangan Orang dalam kualifikasi tindakan perekrutan, pengangkutan, penampungan, pengiriman, pemindahan, atau penerimaan seseorang merupakan unsur perbuatan yang bersifat alternatif; masingmasing tindakan dapat berdiri sendiri yang dilakukan dengan ancaman kekerasan, atau penggunaan kekerasan, atau penculikan, atau penyekapan, atau pemalsuan, atau penipuan, atau penyalahgunaan kekuasaan atau posisi rentan, atau penjeratan utang atau memberi bayaran atau manfaat, untuk tujuan eksploitasi atau mengakibatkan orang tereksploitasi.

Perdagangan orang di kawasan perbatasan berdampak negatif bagi bangsa dan negara
Indonesia; selain melanggar hak asasi manusia dan membawa citra buruk di dunia; terbukti banyak perlakuan yang kurang baik dan kekerasan; serta penganiayaan terhadap tenaga kerja indonesia yang tidak profesional di luar negeri, sehingga harus dilakukan penanggulangan.

Upaya penanggulangan kejahatan perdagangan orang melalui hukum pidana formal (sarana penal) mengarah pada penegakan hukum secara represif (Sudarto, 1981 : 118). Penggunaan sarana penal terhadap perbuatan pengiriman, pemindahan dan penerimaan orang untuk tujuan ekploitasi diharapkan dapat menanggulangi terjadinya kejahatan Perdagangan orang, yang locus delikti sering terjadi di wilayah perbatasan Indonesia dengan Negara lain. Perbatasan darat langsung Indonesia dengan negara tetangga salah satunya terdapat di Kalimantan Barat dengan Sarawak- Malaysia.

Garis batas (boundary line) Kalimantan Barat-Sarawak sepanjang 857 km, dengan wilayah perbatasan di Kalimantan Barat seluas $23.741 \mathrm{Km}^{2}$ saat ini terdapat 2 (dua) jalur pintu masuk resmi; yaitu Pos Lintas Batas (PLB) Entikong-Tebedu di Kecamatan Entikong Kabupaten Sanggau, dan Pos Lintas Batas 
(PLB) Sajingan-Biawak di Kecamatan Sajingan, Kabupaten Sambas dan empat jalur pintu masuk setingkat Pos Pemeriksaan Lintas batas (PPLB) yang dapat dilalui kendaraan baik roda dua dan roda empat yaitu Pos Pemeriksaan Lintas batas (PPLB) Aruk di Kabupaten Sambas, PPLB Badau di Kabupaten Kapuas Hulu, PPLB Jagoi Babang di Kabupaten Bengkayang dan PPLB Jasa di Kabupaten Sintang, dan terdapat lebih dari 54 (lima puluh empat) "jalan tikus" merupakan jalur setapak/jalan perkampungan dapat dilalui kendaraan roda dua untuk masuk ke SarawakMalaysia Timur tanpa dokumen resmi karena tidak ada pos lintas batas maupun pos pemeriksaan lintas batas antar negara, yang memudahkan masyarakat keluar masuk ke Sarawak, Malaysia untuk berbagai kegiatan dan tujuan termasuk pengiriman; pemindahan, atau penerimaan orang untuk bekerja sebagai buruh migran TKI/TKW serta ditunjang biaya transportasi yang relatif murah.

Buruh migran (TKI/TKW) di Malaysia tidak jarang dimanfaatkan pihak-pihak tertentu untuk tujuan diekploitasi dengan melakukan pengiriman; pemindahan atau penerimaan melalui pintu resmi di perbatasan Kalimantan Barat-Sarawak baik menggunakan Paspor, SPLP (Surat Pelaksana Paspor) maupun PLB (Pas Lintas Batas), selain itu juga melalui jalan tikus.

Pasal 1 angka 10 UU No. 21 Tahun 2007 mengatur bahwa Pengiriman orang merupakan "tindakan memberangkatkan atau melabuhkan seseorang dari satu tempat ke tempat lain". Perbatasan darat Negara di Kalimantan Barat dengan Sarawak merupakan Locus Delicti pengiriman perempuan dan anak untuk tujuan ekploitasi dalam kejahatan Perdagangan orang sekaligus sebagai tempat transaksi; pemindahan atau penerimaan perempuan dan anak dari pelaku ke pelaku tindak pidana perdagangan orang lainnya; dalam jaringan kejahatan ini karena adanya peluang memasuki wilayah Sarawak dengan mudah baik melalui pos lintas batas resmi maupun melewati jalan setapak; Jalan tikus di jalur perbatasan yang sehari-hari dilalui oleh penduduk desa-desa di perbatasan Kalimantan Barat-Sarawak pergi-pulang ke dan dari kampung-kampung di negara bagian Sarawak, Malaysia Timur (Neha Misra dan Farida Mahri; , 2003:198). Permasalahan dalam artikel ini adalah Upaya dan hambatan penanggulangan kejahatan perdagangan orang di Perbatasan Kalimantan Barat-Sarawak, serta Kebijakan Pidana yang perlu dilakukan sebagai upaya penanggulangan kejahatan perdagangan orang di Wilayah Perbatasan Kalimantan Barat-Sarawak

\section{B. Metode Penelitian}

Adapun Metode Penelitian dalam mengkaji upaya penanggulangan terhadap kejahatan (PERDAGANGAN) orang di wilayah perbatasan Kalimantan Barat-Sarawak didasarkan pada peraturan perundang-undangan yang berlaku dari Pemerintah/Negara (ius constitutum), dengan mencermati penanggulangan kejahatan perdagangan orang yang telah dilaksanakan di perbatasan Kalimantan Barat-Sarawak (ius Operatum) untuk menemukan ius constituendum dengan berlandaskan ranah kajian socio-legal (FX Adji Samekto, 2010 : 3; Max Webber, 1977 : 88), melalui pendekatan Post-Positivism (FX Adji Samekto, $2012: 78$ ), yang mencermati realitas faktual penanggulangan kejahatan perdagangan orang di wilayah perbatasan Kalimantan BaratSarawak, dan menelaah kebijakan pidana dalam bentuk sarana penal dengan teknik analisis data tipe Strauss dan J. corbin (Strauss dan J cobin, 1990:19) yaitu Langkah pertama yang dilakukan adalah klasifikasi data melalui proses indexing, shorting, grouping, dan filtering. Setelah data dari hasil penelitian dianggap valid dan reliable, langkah berikutnya merekonstruksi dan menganalisisnya secara kualitatif.

\section{Hasil Penelitian dan Pembahasan}

1. Kelemahan Susbtansi Undang-Undang Nomor 21 Tahun 2007 Tentang Tindak Pidana Perdagangan Orang

Kejahatan Perdagangan orang khususnya perempuan dan anak di wilayah perbatasan Kalimantan Barat-Sarawak dapat dikategorikan sebagai kejahatan transnasional (transnational crime) dan secara khusus dapat disebut kejahatan lintas batas (cross-border crime). Kejahatan lintas batas ini juga menjadi Perdagangan orang merupakan tindak kejahatan serius dan merupakan salah satu bentuk pelanggaran HAM, sekaligus merupakan perampasan terhadap hak kemerdekaan, kebebasan berpikir dan hak untuk tidak disiksa.

Substansi Upaya penanggulangan Kejahatan melalui sarana penal merupakan pembatasan (limitation) kekuasaan baik yang dimiliki rakyat maupun kekuasaan/penguasa penegak hukum untuk menjalankan kekuasan sesuai fungsi dan kewenangannya masingmasing dalam ruang lingkup kebijakan hukum pidana.

Kebijakan hukum pidana tertuang dalam UU No. 21 Tahun 2007 merupakan 
upaya pencegahan dan penanggulangan kejahatan perdagangan orang, sebagaimana tercermin dari konsideran UU No. 21 Tahun 2007, keinginan untuk mencegah dan menanggulangi tindak pidana perdagangan orang didasarkan pada nilai-nilai luhur, komitmen nasional, dan internasional untuk melakukan upaya pencegahan sejak dini, penindakan terhadap pelaku, perlindungan korban, dan peningkatan kerja sama baik secara regional maupun Internasional.

Penggunaan sarana penal untuk mempidana pelaku guna menanggulangi Kejahatan Perdagangan orang yang terkualifikasi Tindak Pidana Perdagangan orang (TPPo) harus didasarkan pada unsur kesalahan yaitu Melakukan perbuatan pidana (sifat melawan hukum), Di atas umur tertentu mampu bertanggungjawab, Mempunyai suatu bentuk kesalahan yang berupa kesengajaan atau kealfaan, Tidak adanya alasan pemaaf (Moeljatno, 2008 : 177) sehingga terpenuhi unsur melawan hukum dalam rumusan tindak pidana dan mampu bertanggungjawab secara pidana. Secara kongrit dirumuskan dalam UU No. 21 Tahun 2007 berupa unsurunsur Tindak Pidana Perdagangan orang, subjek hukum atau orang dan atau korporasi yang dikatagorikan sebagai pelaku Tindak Pidana Perdagangan orang, serta ancaman pidana bagi orang dan atau korporasi yang melanggar ketentuan dalam Pasal 2 hingga Pasal 18.

Kebijakan pidana dalam Tahap formulasi UU No. 21 Tahun 2007 merumuskan suatu perbuatan yang dilarang harus memperhatikan secara seksama dan cermat tujuan pembangunan, saat ini dikenal dengan visi dan misi pelaksanaan pembangunan sehingga tidak berdampak pada hal yang tidak diinginkan atau keluar dari tujuan penanggulangan kejahatan. Masalah kriminalisasi, harus diperhatikan: a) Hukum pidana yang digunakan harus memperhatikan Pencapaian Tujuan pembangunan nasional, yaitu mewujudkan masyarakat adil makmur secara material dan spiritual berdasarkan Pancasila; sehubungan itu, hukum pidana digunakan dengan tujuan menanggulangi kejahatan dan mengadakan penganugerahan terhadap tindakan penanggulangan itu sendiri, demi kesejahteraan dan pengayoman masyarakat; b) Usaha mencegah atau menanggulangi perbuatan dengan hukum pidana harus disyaratkan sebagai "perbuatan yang tidak dikehendaki”, yaitu perbuatan yang mendatangkan kerugian (material dan atau spritual) atau warga masyarakat.c) Prinsip biaya dan hasil (cost benefit principle) dalam menggunakan hukum pidana harus pula dihitungkan. d) Kapasitas atau kemampuan daya kerja dari badan-badan penegak hukum harus diperhatikan dalam menggunakan hukum pidana, jangan sampai ada kelampauan beban tugas (overbelasting). Menurut Nigel Walker, penggunaan sarana penal, perlu diperhatikan prinsip-prinsip pembatasan (The limiting principles), antara lain (Barda Nawawi Arief, $1998: 48$ ):

a. Jangan menggunakan hukum pidana semata-mata untuk pembalasan.

b. Jangan menggunakan hukum pidana untuk memidana perbuatan yang tidak merugikan membahayakan.

c. Jangan menggunakan hukum pidana untuk mencapai suatu tujuan yang dapat dicapai secara lebih besar secara lebih efektif dengan sarana-sarana lain yang lebih ringan.

d. Jangan menggunakan hukum pidana apabila kerugian/bahaya yang timbul dari pidana lebih besar dari pada kerugian/ bahaya yang dari perbuatanJtindak pidana itu sendiri.

e. Larangan-larangan hukum pidana jangan mengandung sifat berlebihan dari pada perbuatan yang akan dicegah.

f. Hukum pidana jangan memuat laranganlarangan yang tidak mendapat dukungan kuat dari publik.

g. Hukum pidana jangan memuat larangan ketentuan-ketentuan yang tidak dapat dilaksanakan dipaksakan (unenporceable)

Pendapat M. cherif Bassiouni, yang dikutip Barda Nawawi Arief, Keputusan untuk melakukan kriminalisasi dan dekriminalisasi harus didasarkan pada faktor-faktor kebijakan tertentu yang mempertimbangkan bermacammacam faktor, termasuk (Barda Nawawi Arief, 2008 : 29-30):

a. Keseimbangan sarana-sarana yang digunakan dalam hubungan dengan hasil yang dicari atau yang ingin dicapai (the proportionality of the means used in relationship to the outcome obtained);

b. Analisis biaya terhadap hasil-hasil yang diperoleh dalam hubungan dengan tujuan-tujuan yang dicari (the cost analysis of the outcome obtained in relationship to the objectives sought); 
c. Penilaian atau penafsiran tujuantujuan yang dicari itu dalam kaitannya dengan prioritas-prioritas lainnya dalam pengalokasian sumber-sumber tenaga manusia (the appraisal of the objectives sought in relationship to other priorities in the allocation of resources of human power);

d. Pengaruh sosial dari kriminalisasi dan dekriminalisasi yang berkenaan dengan (dipandang dari) pengaruh-pengaruhnya yang sekunder (the social impact of criminalization and decriminalization in term of its secondary effects) (M cherif Bassiouni, 1992 : 161-162).

Formulasi tindak pidana perdagangan orang dalam Undang-Undang Republik Indonesia Nomor 21 Tahun 2007 Tentang Pemberantasan Tindak Pidana Perdagangan orang prinsipnya ingin mewujudkan perlindungan masyarakat (social defence policy), namun rumusan tindak pidana perdagangan orang masih belum memadai.

a. Pasal 2 ayat (1) UU No 21 Tahun 2007

Pasal ini menentukan unsur yang harus dipenuhi berupa (1) Tindakan (2) cara melakukan (3) Tujuan melakukan, dan dikatagorikan sebagai delik formil, sebaliknya Ayat (2) dikatagorikan delik Materil. Ketiga unsur Tindak Pidana Perdagangan orang dimaksud locus deliktinya dilakukan Di Wilayah Negara Republik Indonesia. Apabila locus delictinya sudah melintasi perbatasan wilayah Indonesia atau di luar negeri, tidak dapat diancam dengan pasal ini. Di wilayah Perbatasan Kalimantan BaratSarawak lebih banyak terekploitasi di Luar Negeri, dan para calo yang melakukan perekrutan, pengangkutan, penggunaan kekerasan, penculikan, penyekapan, pemalsuan, penipuan untuk tujuan ekploitasi di luar negeri, bukan di dalam negeri. Unsur esensial yang harus dipenuhi dalam pasal ini adalah tujuan ekploitasi dan atau terekploitasi di dalam negeri.

b. Pasal 3 UU No. 21 Tahun 2007

Mencermati rumusan kata "memasukkan" di dalam pasal ini apabila dilihat di dalam kamus bahasa Indonesia sebagai kata kerja, diartikan membawa, menyuruh, membiarkan, sehingga ancaman pasal ini ditujukan pada rangkaian perbuatan 'memasukkan orang' dalam arti memasukkan Warga Negara Asing (WNA) atau bukan penduduk Indonesia untuk diekploitasi di Indonesia, atau di keluarkan kembali ke luar negeri untuk diekploitasi di luar negeri, memberi makna yang dilindungi adalah terutama WNA yang dimasukkan ke Wilayah Indonesia untuk di ekploitasi di Indonesia, atau di luar negeri, dan sementara Wilayah Negara Indonesia hanya sebagai daerah transit, namun WNI sendiri untuk tujuan di ekpolitasi di luar negeri tidak dapat diancam dengan Pasal ini. Selain itu perbuatan perdagangan orang di Perbatasan Kalimantan Barat-Sarawak hanya mengeluarkan dari wilayah Indonesia untuk tujuan ekploitasi di luar negeri, sehingga perbuatan mengirim warga negara Indonesia atau penduduk di Wilayah Indonesia tidak dapat diancam dengan Pasal ini, dengan kata lain Pasal ini tidak dimaksudkan untuk melindungi WNI atau Penduduk di Wilayah Indonesia yang dikirim, dipindahkan ke luar negeri untuk tujuan ekploitasi.

c. Pasal 4 UU No. 21 Tahun 2007

Rumusan 'membawa warga negara Indonesia ke luar wilayah negara Republik Indonesia dengan maksud untuk dieksploitasi di luar wilayah negara Republik Indonesia' dalam pasal ini, memberi arti Pelaku (terutama calo) yang melakukan perekrutan, penampungan terhadap Warga Negara Indonesia di dalam negeri untuk di ekplotasi di luar negeri dan belum melakukan perbuatan membawa ke luar wilayah $\mathrm{NRI}$ dengan maksud tujuan eksploitasi di luar wilayah Negara Republik Indonesia (di luar negeri) belum dapat diancam pidana dengan pasal ini secara penuh seperti kejahatan perdagangan orang di wilayah perbatasan Kalimantan BaratSarawak yang terjadi selama ini, hanya dapat diklasifikasikan sebagai Poging terhadap perbuatan membawa ke luar negeri untuk tujuan ekploitasi atau perbuatan deelneming dalam klasifikasi pembujukan (uitloking) untuk dibawa ke luar negeri dengan tujuan ekploitasi, namun UU No. 21 tahun 2007 tidak merumuskan kualifikasi delik (kejahatan atau pelanggaran) sehingga sulit menerapkan ketentuan poging maupun pembantuan, karena Poging terhadap 
pelanggaran tidak dapat dipidana (Pasal $54 \mathrm{KUHP}$ ) dan membantu melakukan pelanggaran juga tidak dapat dipidana (Pasal 60 KUHP)

d. Pasal 5 UU No. 21 Tahun 2007

Rumusan Perbuatan mengangkat anak dengan menjanjikan sesuatu atau memberikan sesuatu untuk maksud dieksploitasi dalam pasal ini, apabila tidak terpenuhi unsur "dengan menjanjikan sesuatu atau memberikan sesuatu" walaupun bertujuan untuk dieksploitasi, maka unsur melawan hukum dalam Pasal ini tidak terpenuhi, apalagi dalam penjelasan Pasal 5 UU No. 21 Tahun 2007 tidak diuraikan makna kata 'menjanjikan sesuatu atau memberikan sesuatu', hanya mencantumkan kata "cukup jelas" sehingga dapat ditafsirkan secara berbeda. Sebaliknya, apabila saat mengangkat anak telah memberikan sesuatu kepada orang tua kandung seorang anak, dan belum terbaca niat/ maksud untuk tujuan mengeklpoitasi, namun setelah anak angkat dipelihara dan kemudian anak angkat diekploitasi, akan sulit melakukan penegakan hukum terhadap pelaku apabila dikaitkan dengan masa kadaluarsa penuntutan Tindak Pidana sesuai ketentuan Pasal 78 KUHP ayat (1) ke-3 yaitu kadaluarsa hak menuntut maksimal sesudah berlalu 12 (dua belas) tahun untuk semua kejahatan yang dapat dipidana dengan pidana penjara lebih dari 3 (tiga) tahun, dan ancaman Pidana Penjara dalam Pasal 5 UU No. 21 Tahun 2007 adalah paling singkat 3 (tiga) tahun dan paling lama 15 (lima belas) tahun, sehingga masa kadaluarsa penuntutan Pasal 5 UU No. 21 Tahun 2007 adalah 12 (dua belas) tahun; Bagi seseorang yang mengangkat anak sejak lahir kemudian setelah anak berusia lebih dari 12 (dua belas) tahun orang tua angkatnya berkeingian mengekploitasi anak angkatnya, maka pasal ini tidak dapat dilakukan penegakan hukumnya. Disamping itu penjelasan Pasal 5 UU No. 21 Tahun 2007 tercantum kalimat "cukup jelas". Apakah menjanjikan sesuatu atau memberikan sesuatu kepada orang tua kandung anak, atau kepada wali dari seorang anak, atau kepada orang yang menguasai seorang anak?, dan apakah maksud pelaku untuk eksploitasi anak angkatnya harus dinyatakan kepada sesuatu kepada orang tua kandung anak, atau kepada wali dari seorang anak, atau kepada orang yang menguasai seorang anak saat menjanjikan sesuatu atau memberikan sesuatu, atau tidak perlu dinyatakan.

e. Pasal 6 UU No. 21 Tahun 2007

Rumusan pasal ini yang berbunyi "pengiriman anak ke dalam atau ke luar negeri dengan cara apa pun yang mengakibatkan anak tersebut tereksploitasi" hanya tertuju pada delik materil, bukan delik formil sehingga terkesan kurang memperhatikan pencegahan terjadinya ekploitasi anak dan kurang mempertimbangkan hak-hak anak yang harus dilindungi, sehingga perbuatan mengirim anak keluar negeri khususnya untuk tujuan ekploitasi tidak dapat dilakukan penegakan hukum. Pasal ini dapat dilakukan penegakan hukumnya apabila perbuatan pengiriman anak ke dalam atau ke luar negeri dengan cara apa pun sudah menimbulkan akibat terekploitasi terhadap anak.

Kasus Kejahatan Perdagangan orang yang terjadi di wilayah Perbatasan Kalimantan Barat-Sarawak, banyak anak yang dikirim, dipindahkan ke Malaysia untuk tujuan ekploitasi, sehingga untuk melakukan penegakan hukum berdasarkan Pasal 6 UU No. 21 Tahun 2007 , harus menunggu anak yang dikirim ke Malaysia untuk diekploitasi timbul akibat terekploitasi di Malaysia dari rangkaian perbuatan pengiriman anak ke luar negeri yang mempunyai kausalitas menimbulkan akibat anak terekploitasi.

f. Pasal 7 UU No. 21 Tahun 2007

Pasal ini apabila dikaitkan dengan Pasal 6 UU No. 21 Tahun 2007 tidak memberikan peluang ancaman pidana kepada pelaku yang mengirim anak ke luar negeri dengan tujuan ekploitasi, padahal banyak kasus yang terjadi di wilayah perbatasan Kalimantan Barat-Sarawak pengiriman anak ke Sarawak, Malaysia untuk tujuan ekploitasi, yang tidak menutup kemungkinan saat melakukan pengiriman sebelum mengakibatkan terekploitasi anak mengalami luka berat dan lainnya, bahkan dalam satu kasus anak dimasukan dalam peti es dan dibius di wilayah perbatasan Kalimantan 
Barat-Sarawak. sehingga tindakan pencegahan secara dini yang diwajibkan dalam Pasal 56 UU No. 21 Tahun 2007 yang merumuskan : "Pencegahan tindak pidana perdagangan orang bertujuan mencegah sedini mungkin terjadinya tindak pidana perdagangan orang" tidak terpenuhi

g. Pasal 8 UU No. 21 Tahun 2007

Pasal ini terlihat kontra dengan Pasal 10 UU No. 21 Tahun 2007, dengan menentukan bahwa orang yang melakukan percobaan untuk melakukan tindak pidana perdagangan orang dipidana dengan pidana yang sama sebagaimana dimaksud dalam Pasal 2, Pasal 3, Pasal 4, Pasal 5, dan Pasal 6 , namun penyelenggara Negara yang menyalahgunakan kekuasaan untuk melakukan tindak pidana perdagangan orang atau mempermudah terjadinya tindak pidana perdagangan orang akan dapat diancam dengan pidana Pasal 2, Pasal 3, Pasal 4, Pasal 5, dan Pasal 6 apabila mengakibatkan terjadinya tindak pidana perdagangan orang (telah terjadi tindak pidana perdagangan orang), apakah penyelenggara Negara yang memberikan dokumen tertentu untuk mempermudah terjadinya tindak pidana perdagangan orang sebelum mengakibatkan terjadinya tindak pidana pedagangan orang tidak dapat diancam pidana sesuai Pasal 2, Pasal 3, Pasal 4, Pasal 5, dan Pasal 6 dan tidak dapat ditambah dengan $1 / 3$ dari ancaman dimaksud, atau penyelenggara Negara yang menyalahgunakan kekuasaan melakukan atau mempermudah percobaan (delict belum selesai /belum menimbulkan terjadinya tindak pidana perdagangan orang) tindak pidana perdagangan orang dipidana tidak dapat diancam dengan Pasal 2, Pasal 3, Pasal 4, Pasal 5, dan Pasal 6 serta ditambah dengan 1/3 dari ancaman dimaksud, sejatinya Pasal 8 UU No. 21 Tahun 2007 merupakan tindak pidana tidak berdiri sendiri, masih digantungkan pada terjadinya tindak pidana perdagangan orang sebagai akibat dari penyalahgunaan kekuasaan yang dilakukan oleh penyelenggara negara. Apabila penyelenggara negara telah menyalahgunakan kekuasannya untuk melakukan atau mempermudah tindak pidana perdagangan orang, tetapi tindak pidana perdagangan orang tidak terjadi maka tidak dapat dilakukan penegakan hukum berdasarkan Pasal 8 UU No. 21 Tahun 2007.

Selain itu rumusan Pasal 8 ayat (1) dengan adanya kata "mengakibatkan" terjadinya tindak pidana perdagangan orang sebagaimana dimaksud dalam Pasal 2, Pasal 3, Pasal 4, Pasal 5, dan Pasal 6 maka pidananya ditambah $1 / 3$ (sepertiga) dari ancaman pidana dalam Pasal 2, Pasal 3, Pasal 4, Pasal 5, dan Pasal 6, seolah-olah penyelenggara negara yang melakukan secara langsung TPPo dengan menyalahgunakan kekuasaanya, namun apabila dibaca dalam penjelasan Pasal 8 ayat (1) penyelenggara negara hanya melakukan perbuatan deelneming.

h. Pasal 9 UU No. 21 Tahun 2007

Pasal ini belum jelas maksud dari berusaha menggerakan orang lain supaya melakukan Tindak Pidana Perdagangan orang, dan tindak pidana itu tidak terjadi, apalagi dalam penjelasannya dikatakan "cukup jelas", apabila dilihat Pasal 55 Ayat (1) KUHP dirumuskan Dipidana sebagai pelaku tindak pidana: ke-1 mereka yang melakukan, yang menyuruh melakukan, dan yang turut serta melakukan perbuatan; ke-2 mereka yang dengan memberi atau menjanjikan sesuatu dengan menyalahgunakan kekuasaan atau martabat, dengan kekerasan, ancaman atau penyesatan, atau dengan memberi kesempatan, sarana atau keterangan, sengaja menganjurkan orang lain supaya melakukan perbuatan. Dan Pasal 55 Ayat (2) KUHP: penganjur dipertanggungjawabkan, hanya perbuatan yang sengaja dianjurkan sajalah yang diperhitungkan, beserta akibat-akibatnya, maka rumusan Pasal 9 UU No. 21 Tahun 2007 tidak termasuk dalam katagori Pasal 55 ayat (1) ke-2 maupun Pasal 55 Ayat (2) KUHP, karena pengaturan Pasal 55 KUHP dimaksudkan perbuatan yang digerakkan/diajurkan harus terjadi minimal percobaannya. Pengaturan rumusan Pasal 9 UU No. 21 Tahun 2007 pada prinsipnya sama dengan Pasal 163 bis KUHP, yang mengancamkan pidana kepada orang yang menggerakan orang lain supaya 
melakukan tindak pidana, dan tindak pidana itu tidak terjadi, tetapi ketidak jelasan rumusan Pasal 9 UU No. 21 Tahun 2007 adalah tidak merinci bahwa tindak pidana perdagangan orang yang tidak terjadi meskipun sudah digerakkan disebabkan oleh apa? Apakah disebabkan oleh kehendak sendiri dari orang yang digerakkan atau hal lain diluar dari orang yang digerakkan, sesuai Pasal 163 ayat (2) bis KUHP bahwa tidak terjadinya suatu tindak pidana yang sudah digerakkan disebabkan kehendak dari orang yang digerakan tidak dapat dipertanggung jawabkan secara pidana. Sehingga pengaturan Pasal 9 UU No. 21 Tahun 2007 mengadopsi ketentuan Pasal 163 bis KUHP tidak dilakukan secara menyeluruh, sehingga masih harus berpegang pada Pasal 163 ayat (2) bis KUHP : Aturan tersebut tidak berlaku, jika tidak mengakibatkan kejahatan atau percobaan kejahatan disebabkan karena kehendaknya sendiri.

i. Pasal 10 UU No.21 tahun 2007

Pasal ini berbeda dengan pengaturan pembantuan dan percobaan dalam KUHP, bahwa : membantu atau melakukan percobaan untuk melakukan tindak pidana perdagangan orang, dianggap sama dengan pelaku dan perbuatan selesai dari sisi ancaman pidananya. Hal ini menunjukkan keinginan pembentuk kebijakan memberantas TPPo seawal mungkin sebelum terjadi TPPo yang dapat membawa kerugian calon korban, dan ini dibenarkan dalam Pasal 103 KUHP.

Namun UU No. 21 Tahun 2007 tidak memuat kualifikasi delik berupa kejahatan atau pelanggaran, sehingga dikaitkan dengan ketentuan Pasal 53 (1) KUHP Mencoba melakukan kejahatan dipidana, jika niat untuk itu telah nyata dari adanya permulaan pelaksanaan, dan tidak selesainya pelaksanaan itu, bukan semata-mata disebabkan karena kehendaknya sendiri, dan Pasal 54 KUHP secara tegas melarang mengancamkan pidana pada tindak pidana berkualifikasi pelanggaran yang berbunyi "Mencoba melakukan pelanggaran tidak dipidana", yang dapat diancam pidana adalah percobaan tindak pidana yang berkualifikasi kejahatan. Konsekuensi yuridis dari tidak adanya pengaturan rumusan kualifikasi delik berupa kejahatan atau pelanggaran dalam UU No. 21 Tahun 2007, maka Pasal 10 UU No.21 tahun 2007 sulit untuk dilaksanakan penegakan hukum terhadap percobaan tindak pidana perdagangan orang.

Demikian pula pengaturan rumusan membantu untuk melakukan tindak pidana perdagangan orang dalam Pasal 10 UU No.21 tahun 2007 dikaitkan dengan ketentuan Pasal 56 KUHP: Dipidana sebagai pembantu kejahatan: 1. mereka yang sengaja memberi bantuan pada waktu kejahatan dilakukan; 2 mereka yang sengaja memberi kesempatan, sarana atau keterangan untuk melakukan kejahatan. Konsekuensi yuridis tidak ada pengaturan rumusan kualifikasi delik berupa kejahatan atau pelanggaran dalam UU No. 21 Tahun 2007, maka rumusan membantu tindak pidana perdagangan orang dalam Pasal 10 UU No.21 tahun 2007 sulit untuk diaplikasikan penegakan hukumnya.

j. $\quad$ Pasal 11 UU No. 21 tahun 2007

Pasal ini merumuskan bahwa merencanakan atau melakukan permufakatan jahat untuk melakukan tindak pidana perdagangan orang dipidana dengan pidana yang sama sebagai pelaku. Hal ini menunjukkan keinginan pembentuk kebijakan memberantas TPPo seawal mungkin sebelum terjadi TPPo yang dapat membawa kerugian calon korban.

Berdasarkan Pasal 88 KUHP bahwa ada permufakatan jahat, apabila dua orang atau lebih telah sepakat akan melakukan kejahatan. Sehingga dikatagorikan mufakat jahat untuk melakukan tindak pidana berkualifikasi kejahatan apabila sudah ada keputusan/ kesepakatan melakukan kejahatan, namun ketentuan Pasal 88 KUHP ini tidak berlaku secara umum bagi tindak pidana di luar KUHP, karena Pasal 88 termasuk dalam Bab IX KUHP yang dimulai dari Pasal 86 sampai dengan Pasal 102 KUHP mengatur atau menentukan istilah-istilah yang hanya digunakan dalam KUHP.

Konsekuensi yuridis harus dirumuskan pengertian 'permufakatan jahat' dengan batas-batasnya harus di rumuskan dalam UU No. 21 Tahun 2007, 
selain itu tidak ada pengaturan rumusan kualifikasi delik berupa kejahatan atau pelanggaran dalam UU No. 21 Tahun 2007, menjadikan Pasal 11 UU No. 21 tahun 2007 sulit diaplikasikan penegakan hukumnya.

k. Pasal 12 UU No. 21 Tahun 2007

Pasal ini terlihat untuk melakukan perlindungan terhadap korban TPPO untuk tidak menjadi korban kedua kali, sebagaimana rumusannya: menggunakan atau memanfaatkan korban tindak pidana perdagangan orang dengan cara melakukan persetubuhan atau perbuatan cabul lainnya dengan korban tindak pidana perdagangan orang, mempekerjakan korban tindak pidana perdagangan orang untuk meneruskan praktik eksploitasi, atau mengambil keuntungan dari hasil tindak pidana perdagangan orang. Rumusan Pasal ini bersesuaian dengan pengaturan Bab V tentang Perlindungan Saksi dan Korban dari Pasal 43 sampai dengan Pasal 55 UU No. 21 Tahun 2007 termasuk didalamnya bersesuaian dengan Undang-Undang Nomor 13 Tahun 2006 tentang Perlindungan Saksi dan Korban

I. Pasal 13 UU No. 21 Tahun 2007

Pasal ini menentukan subjek hukum pelaku Tindak pidana perdagangan orang dilakukan oleh korporasi dengan persyaratan dilakukan oleh orangorang baik sendiri maupun bersamasama bertindak untuk dan/atau atas nama korporasi atau untuk kepentingan korporasi, yang berdasarkan hubungan kerja atau hubungan lain, terkesan mengatur tentang Hukum pidana Formil, namun ditempatkan pada Bab II tentang Tindak Pidana Perdagangan orang, yang mengatur hukum pidana materiil. Selayaknya ditempatkan pada Bab IV tentang Penyidikan, Penuntutan, Dan Pemeriksaan Di Sidang Pengadilan.

m. Pasal 14 UU No.21 Tahun 2007

Pasal ini sama halnya dengan Pasal 13; terkesan mengatur tentang Hukum pidana Formil, namun Pasal 14 UU No.21 Tahun 2007 ditempatkan pada Bab II tentang Tindak Pidana Perdagangan orang, yang mengatur hukum pidana materiil. Selayaknya ditempatkan pada Bab IV tentang Penyidikan, Penuntutan, Dan Pemeriksaan Di Sidang Pengadilan. n. Pasal 15 UU No. 21 Tahun 2007

Pasal ini menunjukkan keinginan pembentuk kebijakan memberantas TPPo yang dilakukan oleh korporasi dengan pemberatan, yang dirumuskan : Dalam hal tindak pidana perdagangan orang dilakukan oleh suatu korporasi, selain pidana penjara dan denda terhadap pengurus korporasi, pidana yang dapat dijatuhkan terhadap korporasi berupa pidana denda dengan pemberatan 3 (tiga) kali, sebagaimana dimaksud dalam Pasal 2, Pasal 3, Pasal 4, Pasal 5, dan Pasal 6 berarti korporasi dapat dijatuhkan pidana denda dengan minimal tiga kali dari seratus dua puluh juta rupiah sebesar tiga ratus enam puluh Juta Rupiah sampai dengan tiga kali enam ratus juta rupiah sama dengan satu milyar delapan ratus Juta Rupiah.

Hal ini menunjukan jumlah denda yang besar bagi korporasi yang tidak mempunyai harta kekayaan, sehingga pidana denda tidak dapat dibayarkan, namun UU No. 21 Tahun 2007 tidak mengatur Aturan Pidana Pengganti Denda bagi Korporasi. Dengan demikian pidana denda bagi korporasi sulit untuk dieksekusi.

o. Pasal 16 UU No. 21 Tahun 2007

Pasal ini menentukan bahwa TPPo yang dilakukan oleh kelompok yang terorganisasi, maka setiap pelaku tindak pidana perdagangan orang dalam kelompok yang terorganisasi tersebut dipidana. Hal ini menunjukkan keinginan pembentuk kebijakan memberantas TPPo yang dilakukan oleh kelompok orang dengan pemberatan, namun tidak semua pasal dalam UU TPPo dapat diperberat sesuai pengaturan Pasal 16 UU No. 21 Tahun 2007 ini, hanya Pasal 2 , yang locus deliktinya terjadi di dalam negeri, padahal bila di lihat dari praktek Kejahatan Perdagangan Perempuan dan Anak di wilayah Perbatasan Kalimantan Barat-Sarawak, banyak terjadi TPPo dilakukan berkelompok yang terorganisir mulai dari perekrutan, hingga melintasi perbatasan baik untuk tujuan ekploitasi maupun mengakibatkan terekploitasi, dan tidak hanya rumusan Pasal 2 yang dapat dilakukan secara berkelompok yang terorganisir.

Demikian pula apabila dilihat dari penjelasan Pasal 16 UU No. 21 Tahun 
2007 ini yang memberi pengertian "kelompok yang terorganisasi" adalah kelompok terstruktur yang terdiri dari 3 (tiga) orang atau lebih, yang eksistensinya untuk waktu tertentu dan bertindak dengan tujuan melakukan satu atau lebih tindak pidana yang diatur dalam Undang-Undang ini dengan tujuan memperoleh keuntungan materiil atau finansial baik langsung maupun tidak langsung. Sebaliknya Pasal 1 angka 6 memberi pengertiaan bahwa Korporasi adalah kumpulan orang dan/ atau kekayaan yang terorganisasi baik merupakan badan hukum maupun bukan badan hukum, sehingga terkesan jumbuh dengan pengaturan dalam Pasal 15 UU No.21 Tahun 2007.

p. Pasal 17 UU No. 21 Tahun 2007

Pasal ini terkesan kurang konsistensi dan tidak mengacu pada pola rasionalitas yang sama dalam penilaian bobot delict dan ancaman sanksi pidana.

Pasal 17 UU No. 21 Tahun 2007 ini menambah ancaman dengan 1/3 untuk Pasal 2, 3 dan 4 apabila korbanya anak, namun ancaman pidana dalam pasal 5 , 6 yang secara jelas objek korbannya anak ancamannya sama dengan pasal 2 , 3, 4 dan tidak lebih berat dari ancaman pidana dalam Pasal 2, Pasal 3 dan Pasal 4 UU No. 21 Tahun 2007.

q. Pasal 18 UU No. 21 Tahun 2007

Pasal ini merumuskan Tidak dipidana, bagi korban TPPo yang melakukan tindak pidana karena dipaksa oleh pelaku tindak pidana perdagangan orang. Perumusan unsur overmacht (keterpaksaan) sebagai alasan pemaaf dalam pasal ini, sama dengan pengaturan Pasal 48 KUHP.

Faktor substansi hukum saling berkaitan erat dengan faktor penegak hukum yang menempati titik sentral dalam penegakan hukum sebagai tolak ukur sampai sejauh mana kontribusi penanggulangan kejahatan bagi kesejahteraan masyarakat (Soerjono Soekanto, 2005 : 69).

Pembahasan penegakan hukum dari sisi perundang-undangan Tindak Pidana Pemberantasan Perdagangan orang sebagaimana diatur dalam UU No. 21 Tahun 2007 di atas dapat dikatakan sebagai salah satu hambatan.
2. Implementasi Penegakan Hukum Tindak Pidana Perdagangan Orang di Perbatasan Kalimantan Barat-Serawak

Faktor penegak hukum yang mengaplikasikan Undang-undang tindak pidana pemberantasan perdagangan orang juga dapat menjadi hambatan untuk memberantas kejahatan perdagangan orang di perbatasan Kalimantan BaratSarawak, apabila dibandingkan jumlah personil kepolisian yang bertugas di wilayah perbatasan dengan dengan luas dan panjangnya wilayah perbatasan.

Tidak kalah pentingnya dalam penanggulangan tindak pidana perdagangan orang diperbatasan Kalimantan BaratSarawak dari sisi budaya, masyarakat perbatasan memiliki kesamaan budaya dengan masyarakat di Sarawak Malaysia, bahkan masih mempunyai tali persaudaraan sehingga terdapat hubungan emosional yang sangat kuat diantara kedua kelompok masyarakat, mereka saling mengujungi satu dengan lainnya walaupun tidak menggunakan dokumen resmi. Hal ini banyak dimanfaatkan oleh para calo, pelaku tindak pidana perdagangan orang di Perbatasan Kalimantan Barat-Sarawak dalam memelakukan tindakan pengiriman, pemindahan, penerimaan orang.

Faktor geografis perbatasan darat Kalimantan Barat-Sarawak yang berhimpitan secara langsung, panjangnya lintas perbatasan ditambah Jalan Lintas Batas tidak semuanya memiliki Pos Pengamanan Perbatasan, banyaknya jalan setapak yang dapat dilalui untuk menuju ke Sarawak, juga salah satu hambatan dalam penanggulangan kejahatan perdagangan orang di Wilayah perbatasan Kalimantan Barat-Sarawak, terutama dengan modus operandi Tenaga kerja migran, Penjualan bayi ke luar negeri.

Hambatan lain dalam berkenaan dengan kesenjangan Tingkat Kesejahteraan Masyarakat di wilayah Perbatasan Kalimantan Barat dengan Masyarakat di wilayah Perbatasan Sarawak, Keterbatasan prasarana wilayah dan sarana sosial serta kurangnya akses keluar masyarakat perbatasan hanya dengan Sarawak (Malaysia), sebagai contoh terbatasnya jangkauan media massa cetak maupun elektronik yang bersumber dari Indonesia, bahkan tidak dapat dijangkau, sehingga penduduk di Perbatasan Kalimantan Barat-Sarawak lebih cenderung menikmati media massa; siaran televisi, radio dari luar negeri (Malaysia). 
Kebijakan hukum pidana dalam memformulasikan tindak pidana dan penanggulangan tindak pidana dapat dilakukan sesuai dengan kebijakan pembangunan masyarakat/sosial global yang mengacu pada kongres Perserikatan Bangsa-Bangsa (PBB), sebagaimana dikutip Sudarto,yaitu (Sudarto, $1986: 27$ ):

a. Strategi dasar/pokok penanggulangan kejahatan, ialah meniadakan faktor-faktor penyebab/kondisi yang menimbulkan terjadinya kejahatan.

b. Pencegahan kejahatan dan Peradilan Pidana harus ditempuh dengan kebijakan integral/sistemik (jangan simplistic dan pragmentair).

c. Perlu memperhatikan beberapa kejahatan-kejahatan tertentu yang sifatnya transnasional, regional, dan internasional, yang berhubungan dengan kejahatan modern.

d. Perlu dibenahi dan ditingkatkan kualitas aparat penegak hukum.

e. Perlu dibenahi dan ditingkatkan kualitas institusi dan managemen organisasi/ managemen data.

f. Perlu disusunnya Guidelines, Basic Principle, Rules, Standard Minimum Rules (SMR).

g. Perlu ditingkatkan kerja sama intenasional dan bantuan teknis, dalam rangka memperkukuh the rule of law dan management of criminal justice system.

Hakikat kebijakan hukum pidana adalah proses penegakan hukum pidana secara menyeluruh, melalui tahap formulasi, aplikasi dan eksekusi. Tahap Formulasi dikenal sebagai penegakan hukum secara abstrak, yang meletakan dasar dan tolak ukur untuk melaksanakan penegakan hukum secara kongkrit yaitu tahap aplikasi dan tahap eksekusi.

Aplikasi penegakan hukum Kejahatan Perdagangan orang selain berpedoman pada UU pemberantasan TPPo harus pula mencermati lingkungan sosial masyarakat. Bekerjanya hukum di masyarakat dalam melakukan penegakan hukum, y ang dipengaruhi pula oleh lingkungan sosial di masyarakat, sebagaimana upaya penanggulangan kejahatan perdagangan orang, penegakan hukum terhadap kejahatan perdagangan orang di Wilayah Perbatasan Kalimantan Barat dalam memformulasikan Tindak pidana sebagai aturan normatif dalam UU No. 21 Tahun 2007 tentang Pemberantasan TPPo, harus didasarkan pada modus dan motif kejahatan perdagangan orang, serta memperhatikan kondisi dan peranserta masyarakat secara faktual.

Berbagai bentuk tindakan baik berupa perekrutan, penampungan, pengiriman, pemindahan hingga gaji tidak dibayarkan atau pembayaran gaji yang tidak sesuai dengan yang diperjanjikan dan dilakukan dengan berbagai modus operandi melalui penipuan, bujuk rayu yang dilakukan pelaku telah ditemukan beberapa kasus yang terkualifikasi sebagai kejahatan perdagangan orang; tetapi disangkakan dengan UU No. 39 Tahun 2004 Tentang Penempatan Dan Perlindungan Tenaga Kerja Indonesia di Luar Negeri, meskipun apabila dicermati modus operandi pelaku dapat dikualifikasi sebagai kejahatan perdagangan orang dan bahkan diantaranya memenuhi unsur tindak pidana dalam UU No. 21 Tahun 2007.

Aplikasi Penegakan hukum kurang optimal terhadap kejahatan Perdagangan orang di Perbatasan Kalimantan BaratSarawak tidak terlepas dari substansi perundang-undangan yang kurang memadai, dalam hal ini UU No. 21 Tahun 2007, Pembuat (lembaga Legislatif) UU No. 21 Tahun 2007 Tentang Pemberantasan Tindak Pidana Perdagangan orang kurang maksimal mencermati modus operandi dan prediksi perkembangan kejahatan perdagangan orang khususnya di wilayah perbatasan.

Selain aplikasi Penegakan hukum kejahatan Perdagangan orang juga kurang optimal dilakukan penyelidik, penyidik yang termasuk garda terdepan pelaksana penegakan hukum, dan dan penuntut umum selalu mengandalkan formalistis perundang-undangan, khususnya hakim belum maksimal menggali hukum yang hidup dalam masyarakat dalam mengadili dan memutuskan kejahatan perdagangan orang. Selain itu peranan masyarakat belum optimal dalam menanggulangi kejahatan perdagangan orang terutama masyarakat yang berdomisili di wilayah perbatasan Kalimantan Barat-Sarawak.

\section{Simpulan}

1. Upaya penanggulangan Kejahatan Perdagangan orang di wilayah Perbatasan Kalimantan Barat-Sarawak telah dilakukan melalui sarana penal (kebijakan hukum 
pidana) oleh aparat yang berwenang, namun masih terjadi kejahatan perdagangan orang, karena masih terdapat berbagai hambatan dari substansi penal, yang belum memuat kualifkasi delik; dan unsur TPPo belum selaras dengan modus operandi.

2. Upaya penanggulangan kejahatan perdagangan orang di wilayah perbatasan Kalimantan Barat-Sarawak dapat dilakukan melalui kebijakan hukum pidana dengan menselaraskan Kebijakan Formulasi hukum pidana in abstracto tertuju pada substansi hukum pidana materiil berdasarkan pada modus operandi kejahatan perdagangan orang, perlindungan masyarakat, dan menselaraskan dengan Kebijakan Aplikasi hukum pidana In-concreto.

\section{E. Saran}

Berlandaskan pada simpulan, disarankan untuk memperbaiki rumusan tindak pidana perdagangan orang sesuai dengan modus operandi dan prediksi kejahatan perdagangan orang, serta mencanangkan asas hukum pemidanaan nilainilai kepatutan terhadap perbuatan/tindakan yang dinilai bertentangan dengan nilai-nilai kepatutan dan diakui sebagai kejahatan dalam masyarakat, yang bersesuaian dengan nilai-nilai Pancasila dan UUD NRI 1945.

\section{daftar Pustaka}

Ali, Ahmad; Menguak Tabir Hukum (Suatu kajian filosofis dan Sosiologis), Gunung Agung, Jakarta,2002

Arief, Barda Nawawi; Beberapa Aspek Kebijakan Penegakan dan Pengembangan Hukum Pidana, PT. citra Aditya Bakti, Bandung, 1998

; Bunga Rampai Kebijakan Hukum Pidana (Perkembangan Penyusunan Konsep KUHP Baru), Kencana Prenada Media Group,Jakarta, 2008

; Masalah Penegakan hukum dan Kebijakan Hukum Pidana dan Penanggulangan Kejahatan, Kencana Prenada Media Group,2008

; Kebijakan Legeslatif dalam Penanggulangan Kejahatan dengan Pidana Penjara, cet. Ke-4, Genta Publising, Yogjakarta, 2009

; Tujuan dan Pedoman Pemidanaan; Perspektif Pembaharuan dan Perbandingan Pidana), Pustaka Magister, Semarang, 2011

; "Penanggulangan Kejahatan Transnasional Di Daerah Perbatasan Indonesia - Negara Tetangga"; Makalah dalam Seminar Nasional "Pembangunan Kawasan Perbatasan Indonesia (Kalbar-Sarawak)”, Program Magister Ilmu Hukum, UNTAN, Pontianak, 16 September 2006

Friedman, Lawrence M.; dalam The Legal System; A Social Scince Prespective, Russel Sage Foundation, New York, 1975

;"What Is a Legal System" American Law. W.W. Norton \& company, New York. 1984

; The Legal System; A Social Science Prespective, terjemahan M.Khozim, PT. Nusa Media, Bandung. 2009

Hamzah, Andi; Asas-asas Hukum Pidana, Edisi Revisi, Bhineka cipta, Jakarta, 1994.

Kapolda Kalimantan Barat, Brigjen Pol. Drs. Edwin TPL Tobing, "Paparan Kasus Traffiking”, Makalah Seminar. Polda Kalbar, 16 oktober 2007

Misra, Neha dan Farida Mahri; Kalimantan Barat, dalam Perdagangan Perempuan dan Anak di Indonesia oleh Ruth Rosenberg, United States Agency for International Development (USAID), 2003

Moeljatno, Asas-asas Hukum Pidana, ed.revisi, Rineka cipta, Jakarta, 2008

Muladi; Hak Asasi Manusia, Politik dan Sistem Peradilan Pidana, Badan Penerbit UND1P, Semarang, 1997

Rosenberg, Ruth; Perdagangan Perempuan dan Anak di Indonesia, United States Agency for International Development (USAID), 2003 
Reksodiputro, Mardjono; Hak Asasi Manusia Dalam Sistem Peradilan Pidana, Kumpulan Karangan Buku Ketiga. Pusat Pelayanan Keadilan dan Pengabdian Hukum Universitas Indonesia, Jakarta, 1994.

Saleh, Roeslan; Perkembangan Asas-asas Hukum Pidana, Diktat, Tanpa kota, tanpa penerbit, tanpa tahun.

Samekto, FX. Adji; IImu Hukum dalam pergeseran Pemikiran Menuju Post- Modernisme, PDIH UNDIP, Semarang, 2012,

, Pengantar konstruksi berpikir Penulisan Karya Ilmu Hukum Dalam Kajian Sociolegal studies, makalah, FH UNDIP 2010

Serikat Putra Jaya, Nyoman ; Beberapa Pemikiran Ke arah Pengembangan Hukum Pidana, citra Aditya Bakti, Bandung 2008

Strauss,A. and J. cobin, Busir, Qualitative Research; Gounded Thepry Procedue and Techniques, London, Sage Publication, 1990.

Sudarto, Kapita Selekta Hukum Pidana, Alumni Bandung, 1986

, Hukum dan Perkembangan Masyarakat, Sinar Baru, Bandung, 1983.

, Pembaharuan Hukum Pidana Indonesia, Simposium Pembaharuan Hukum Pidana Nasional, Badan Pembinaan Hukum Nasional Departemen Kehakiman Republik Indonesia, Bina cipta, Bandung, 1986 